\title{
PENGARUH MODEL PEMBELAJARAN KANCING GEMERINCING TERHADAP HASIL BELAJAR IPA KELAS V
}

\author{
I Komang Sucipta ${ }^{1}$, I Gusti Ngurah Japa ${ }^{2}$, I Gede Margunayasa ${ }^{3}$ \\ 1,2,3 Jurusan Pendidikan Guru Sekolah Dasar, Universitas Pendidikan Ganesha \\ Singaraja, Indonesia \\ e-mail: mangsucipta2@outlook.com, igustingurah.japa@undiksha.ac.id, \\ igede.margunayasa@undiksha.ac.id
}

\begin{abstract}
Abstrak
Penelitian ini bertujuan untuk mengetahui pengaruh yang signifikan hasil belajar IPA antara kelompok siswa yang dibelajarkan melalui pengaruh model pembelajaran kooperatif tipe kancing gemerincing dengan kelompok siswa yang dibelajarkan tidak menggunakan model pembelajaran kooperatif tipe kancing gemerincing pada siswa kelas V SD Negeri di Gugus IV Kecamatan Sidemen. Penelitian ini merupakan penelitian eksperimen semu dengan rancangan Equivalent post test only kontrol group design. Populasi penelitian adalah siswa kelas V SD Negeri di Gugus IV Kecamatan Sidemen. Sampel pada penelitian ini adalah siswa kelas V SD Negeri 3 Sangkan Gunung sebagai kelompok eksperimen dan siswa kelas V SD Negeri 6 Sangkan Gunung sebagai kelompok kontrol. Penentuan kelompok eksperimen dan kontrol menggunakan teknik random sampling. Pengumpulan data hasil belajar IPA dilakukan dengan metode tes dan instrumen yang digunakan adalah berupa tes objektif pilihan ganda. Data yang dikumpulkan dianalisis menggunakan analisis statistik deskriptif dan statistik inferensial (uji-t). Berdasarkan hasil analisis data, diperoleh bahwa thitung $(3,65)>\operatorname{ttabel}(2,01)$, sehingga $\mathrm{H} 0$ ditolak dan $\mathrm{H} 1$ diterima yang berarti terdapat pengaruh yang signifikan. Rerata hasil belajar IPA pada kelompok eksperimen yaitu 14,12 dan kelompok kontrol yaitu 9,75. Dengan demikian, dapat disimpulkan bahwa penerapan model pembelajaran kooperatif tipe kancing gemerincing berpengaruh positif terhadap hasil belajar IPA siswa kelas V Gugus IV Kecamatan Sidemen tahun pelajaran 2017/2018.
\end{abstract}

Kata kunci: hasil belajar, IPA, kancing gemerincing

\begin{abstract}
The purpose of this research was to know the significant effect the learning result of science subject between the group students that were taught through the effect of cooperative learning model that the type was Talking Chips and the group students that were taught without using cooperative learning model that the type was Talking Chips in which the students were five grade of elementary school cluster IV in Sidemen sub district. This research was an apparent experiment with the design was equivalent posttest only kontrol group design. The population of the research was the students of five grade of elementary school cluster IV in Sidemen sub district. The sample of this research was five graders of SD Negeri 3 Sangkan Gunung as the experimental group, and five graders of SD Negeri 6 Sangkan Gunung as the control group. In determining the experiment and control group, it was used random sampling technique. The data collection of the learning result of science was done with the test method, and the instrument that was used was a multiple choice objective test. The collected data was analyzed by using descriptive analysis statistic and inferential analysis statistic (t-test). From the data analysis, it was found that thit (3.65) > ttab (2.01), so that $\mathrm{HO}$ was refused which means that there was a significant effect. The average of the learning result of science in the experimental group was 14.12 , while the control group was 9.75 . Thereby, it can be concluded that the application of cooperative learning model of Talking Chips
\end{abstract}


type affects positive towards the learning result of science five grade cluster IV in Sidemen sub district in academic year of 2017/2018.

Keywords: achievement, science, talking chips

\section{Pendahuluan}

Pendidikan merupakan suatu bidang yang sangat penting bagi kehidupan manusia, karena pendidikan merupakan usaha manusia dalam mengembangkan potensi yang dimiliki menuju kedewasaannya, baik secara mental, intelektual, dan emosional. Pendidikan memiliki fungsi sebagai peningkatan sumber daya manusia dan memiliki korelasi yang positif terhadap kesejahteraan. Dalam upaya untuk lebih mewujudkan fungsi pendidikan tersebut, maka perlu dikembangkan iklim belajar mengajar yang konstruktif bagi berkembangnya potensi kreatif peserta didik seiring dengan berkembangnya suasana, kebiasaan dan strategi belajar mengajar. Pendidikan juga merupakan sarana untuk menyiapkan generasi masa kini dan masa depan. Hal ini dapat diartikan bahwa proses pendidikan yang diberikan bukan semata-mata untuk hari ini, melainkan untuk masa depan.

Pembelajaran yang baik mampu mengembangkan seluruh potensi yang dimiliki siswa dengan melibatkan siswa secara langsung dalam pembelajaran. Guru perlu meningkatkan mutu pembelajaran, dimulai dengan menyusun rancangan pembelajaran yang baik dengan memperhatikan tujuan, karakteristik siswa, materi yang diajarkan, dan sumber belajar yang tersedia. Terdapat pembelajaran yang dari dulu sampai sekarang prosesnya belum maksimal karena dalam pelaksanaannya hanya mengedepankan metode ceramah, dan penugasan yaitu pembelajaran IPA di sekolah dasar. Pada pembelajaran IPA perlu ditingkatkan mutunya dengan menggunakan pembelajaran yang inovatif.

Mata Pelajaran IPA di sekolah dasar sangat penting bagi perkembangan pendidikan anak. Secara khusus pembelajaran IPA dewasa ini berkembang amat pesat. Mengingat pentingnya peranan IPA dalam kehidupan sehari-hari, terutama berkaitan dengan perkembangan IPTEK dan perkembangan industri. Proses pembelajaran IPA menuntut keterlibatan siswa secara aktif dalam proses pembelajaran. Peran IPA dalam pembelajaran tidak dapat disangkal lagi. Setiap siswa dituntut mampu menguasai IPA karena merupakan suatu pelajaran yang berkaitan erat dengan lingkungan alam sekitar secara berkesinambungan yang dapat memupuk rasa ingin tahu siswa secara ilmiah, sehingga dapat membantu siswa mengembangkan kemampuan bertanya dan mencari jawaban atas dasar bukti serta mengembangkan cara berfikir ilmiah siswa.

Mencermati hal tersebut, penggunaan model pembelajaran yang inovatif yang dapat diterapkan pada pembelajaran IPA di SD yaitu model pembelajaran Kancing Gemerincing. Model pembelajaran interaktif karena menekankan pada keterlibatan aktif siswa selama proses pembelajaran. Model kancing gemerincing adalah cara penyajian materi ajar dalam bentuk permainan kancing secara begilir dan siswa dituntut untuk menghabiskan kancing satu persatu dengan cara menjawab atau mengajukan pertanyaan disertai dengan pemberian penguatan apabila siswa tidak bisa menjawab dengan benar.

Model pembelajaran kancing gemerincing dapat diartikan pembelajaran yang dirancang untuk mengukur tingkat penguasaan materi pelajaran oleh siswa dengan menggunakan media kancing. Kagan (dalam Miftakhul, 2011: 142) berpendapat bahwa, model pembelajaran kooperatif tipe kancing gemerincing adalah jenis metode struktural yang mengembangkan hubungan timbal balik antar anggota kelompok dengan didasari adanya kepentingan yang sama. Setiap anggota mendapatkan chips yang berbeda yang harus digunakan setiap kali mereka ingin berbicara mengenai: menyatakan keraguan, menjawab pertanyaan, bertanya, mengungkapkan ide, mengklarifikasi pertanyaan, mengklarifikasi ide, merangkum, mendorong 
partisipasi anggota lainnya, memberikan penghargaan untuk ide yang dikemukakan anggota lainnya dengan mengatakan hal yang positif. Sedangkan Lie (2004:63) menyatakan dalam kegiatan pembelajaran Kancing Gemerincing, masing-masing anggota kelompok mendapatkan kesempatan untuk memberikan kontribusi mereka dengan mendengarkan pandangan dan pemikiran anggota yang lain.

Model kancing gemerincing sangat sederhana dan cukup mudah untuk diterapkan pada pembelajaran. Model pembelajaran ini bertujuan agar siswa mau berpendapat dan juga untuk melatih siswa berani berbicara. Siswa yang mendapat kesempatan diwajibkan menjawab pertanyaan atau mengajukan pertanyaan hingga kancing yang dimiliki habis. Kegiatan terakhir guru memberikan kesempatan kepada peserta didik melakukan refleksi terhadap materi yang telah dipelajarinya.

Sugianto (2010:57) menyebutkan model pembelajaran kooperatif tipe kancing gemerincing memiliki 4 langkah sebagai berikut. (1) guru menyiapkan satu kotak kecil yang berisi kancingkancing (bisa juga menggunakan benda-benda kecil lainnya). (2) sebelum kelompok memulai tugasnya, setiap siswa dalam masing-masing kelompok mendapatkan dua atau tiga buah kancing (jumlah kancing bergantung kesulitan tugas yang diberikan). (3) setiap kali seorang siswa berbicara atau mengeluarkan pendapat, dia harus menyerahkan satu kancingnya dan meletakkannya di tengah-tengah. (4) jika kancing yang dimiliki sudah habis, siswa tidak boleh berbicara lagi sampai semua rekannya juga menghabiskan kancing mereka. Jika semua kancing sudah habis, sedangkan tugas belum selesai, kelompok boleh mengambil kesempatan untuk membagi kancing lagi dan mengulangi prosedur kembali.

Keunggulan dari teknik ini adalah untuk mengatasi hambatan pemerataan kesempatan yang sering mewarnai kerja kelompok. Dalam banyak kelompok sering ada anggota yang tidak aktif dan pasrah saja pada rekannya yang lebih dominan. Anggota kelompok yang tidak aktif akan merasa malas untuk bekerja dalam kelompok karena merasa sudah ada anggota kelompok yang bekerja lebih aktif. Dalam situasi seperti ini, pemerataan tanggung jawab tidak bisa tercapai karena anggota yang tidak aktif akan terlalu menggantungkan diri pada rekannya yang dominan. Teknik belajar kancing gemerincing memastikan bahwa setiap siswa mendapatkan kesempatan untuk berperan serta dalam pembelajaran

Namun, kondisi guru disekolah memilih menggunakan metode-metode seperti metode ceramah, diskusi, tanya jawab dan latihan soal. Metode tersebut digunakan secara terus menerus membuat siswa mengalami kurang motivasi dan kurang dalam mencapai hasil belajar IPA. Hal itu terlihat dari hasil wawancara dan pengumpulan dukumen yang telah dilakukan. Berdasarkan hasil wawancara dan pengumpulan dokumen pada kegiatan pembelajaran IPA di SD Gugus IV Kecamatan Sidemen guru tidak melakukan proses belajar mengajar sesuai dengan paradigma belajar mengajar yang inovatif dan kreatif, pembelajaran yang dilakukan berpusat pada guru (teacher centered) dengan menggunakan metode ceramah, metode diskusi, metode tanya jawab dan metode latihan soal yang menyebabkan guru tidak memiliki persiapan dalam mengajar sehingga siswa kurang aktif dan merasa bosan dalam proses pembelajaran.

Penggunaan model pembelajaran kancing gemerincing sangat cocok untuk membuat siswa aktif dalam proses pembelajaran karena dalam penerapannya semua siswa ikut dalam kegiatan dan harus berkonstrasi untuk menyimak materi yang disampaikan oleh guru. Siswa akan mengingat materi pembelajaran yang telah disampaikan untuk menjawab pertanyaan yang akan diberikan. Setiap siswa akan bertanggung jawab terhadap atas dirinya sendiri. Siswa akan terpacu untuk menjawab pertanyaan agar jawabannya yang disampaikan benar. Dalam proses pembelajaran dengan menggunakan model pembelajaran kancing gemerincing guru harus mampu berperan sebagai motivator dan fasilitator agar proses pembelajaran dapat berlangsung dengan efektif. Guru harus memiliki wawasan pengetahuan yang luas dan mampu memanfaatkan teknologi modern, dan potensi lingkungan sekitar untuk dijadikan sebagai 
sumber belajar. Setiap akhir proses pembelajaran diakhiri dengan evaluasi untuk mengukur keberhasilan prose pembelajaran.

Penelitian ini bertujuan untuk mengetahui perbedaan yang sifnifikan hasil belajar IPA antara siswa yang dibelajarkan dengan model pembelajaran kooperatif tipe kancing gemerincing dengan siswa yang dibelajarkan tidak menggunakan model pembelajaran kooperatif tipe kancing gemericing pada siswa kelas $\mathrm{V}$ di gugus IV kecamatan Sidemen tahun pelajaran 2017/2018.

\section{Metode}

Penelitian ini dilaksanakan di Gugus IV Kecamatan Sidemen. Kegiatan pelitian ini dilaksanakan pada semester I tahun pelajaran 2017/2018. Jenis penelitian yang dilakukan adalah penelitian eksperimen semu. Rancangan penelitian yang digunakan adalah Equivalent post test only kontrol design. Populasi dalam penelitian ini adalah kelas V di Gugus IV Kecamatan Sidemen yang terdiri dari 6 Sekolah Dasar yaitu, SD Negeri 1 Sangkan Gunung, SD Negeri 2 Sangkan Gunung, SD Negeri 3 Sangkan Gunung, SD Negeri 4 Sangkan Gunung, SD Negeri 5 Sangkan Gunung, dan SD Negeri 6 Sangkan Gunung tahun pelajaran 2017/2018. Teknik pengambilan sampel yang digunakan dalam penelitian ini adalah Teknik random sampling yaitu dengan Teknik undian. Untuk mengetahui kemampuan siswa kelas $\mathrm{V}$ masingmasing dari Gugu IV Kecamatan Sidemen setara atau tidak, maka terlebih dahulu dilakukan uji kesetaraan dengan menggunakan ANAVA satu jalur.

Berdasarkan Uji ANAVA satu jalur diketahui bahwa kelas V di Gugus IV Kecamatan Sidemen merupakan kelas yang setara. Dengan hasil Fhitung $=0,67$ dan Ftabel $=2,16$, ini berarti Fhitung < Ftabel. Pada tahap ke dua, berdasarkan uji kesetaraan, maka sekolah yang setara tersebut akan diundi secara acak dari sampel yang sudah lolos uji kesetaraan, untuk menentukan sekolah yang akan dijadikan sebagai tempat penelitian. Dari hasil undian diperoleh dua sekolah yaitu SD Negeri 3 Sangkan Gunung dan SD Negeri 6 Sangkan Gunung. Selanjutnya tahap ketiga, sekolah yang telah terpilih kembali di undi secara acak untuk menentukan kelas eksperimen dan kelas kontrol. Hasil pengundian menyatakan SD Negeri 3 Sangkan Gunung sebagai kelas eksperimen, sementara SD Negeri 6 Sangkan Gunung sebagai kelas kontrol.

Variabel yang terlibat dalam penelitian ini adalah sebagai berikut (1) variabel bebas dalam penelitian ini adalah model pembelajaran kancing gemerincing, yang diterapkan pada kelas eksperimen dan kelompok kontrol yang tidak diberikan perlakuan. (2) variabel terikat dalam penelitian ini adalah hasil belajar IPA siswa kelas V SD Gugus IV Kecamatan Sidemen.

Hasil belajar yang dimaksud pada penelitian ini adalah hasil belajar aspek kognitif. Hasil belajar IPA diukur dengan metode tes dengan instrument berupa lembar soal pilihan ganda sebanyak 20 butir soal. Penskorannya menggunakan rubrik penilaian. Setiap soal memiliki skor 0-1. Jika soal dijawab benar maka skor yang didapat adalah 1 sedangkan soal yang dijawab salah maka skor yang didapat adalah 0 .

Data yang diperoleh dari uji coba instrument dianalisis dengan menggunakan uji validitas butir tes, uji reliabilitas tes, indeks daya beda, dan indeks kesukaran butir. Pada penelitian ini, analisis dilakukan dengan menggunakan bantuan program Microsoft Office Excel 2013.

Data yang pertama didapat yaitu uji validitas. Terdapat 40 soal yang akan terlebih dahulu di uji judges dan hasil dianalisis dengan perhitungan Gregory. Berdasarkan perhitungan menurut Gregory,38 butir tes tersebut berada pada kriteria validitas tes hasil belajar sangat tinggi yaitu bera pada rentangan 0,80 - 1,00 yang artinga 38 butir soal dikatakan relevan. Dari 
40 butir soal tersebut dipilih 25 butir soal yang selanjutnya di uji cobakan kepada 50 orang siswa kelas VIA dan VIB di SD Mutiara Singaraja. Kemudian hasilnya dianalisis dengan dilakukan uji validitas butir tes dengan rumus korelasi point biserial. Hasil rxyhitung dengan dikonsultasikan dengan taraf signifikasi 5\%. Berdasarkan hasil analisis, 23 butir soal yang diuji dinyatakan valid.

Analisis kedua yaitu 23 butir soal yang sudah dinyatakan valid diuji reabilitas dengan menggunakan formula Kuder Richadson 20 (KR-20). Berdasarkan perhitungan dengan rumus tersebut, dari 23 soal diperoleh reliabilitas tes hasil belajar IPA $=0,904$ dengan derajat reliabilitas tes tergolong sangat tinggi.

Analisi ketiga adalah indeks daya beda. Berdasarkan perhitungan indeks daya beda diperoleh 3 butir soal kurang baik, maka 3 butir soal tersebut tidak dipakai dan sisanya 20 soal akan dipakai untuk post test hasil belajar IPA.

Analisis terakhir adalah indeks kesukaran butir. Dari hasil perhitungan dengan rumus indeks kesukaran butir soal menunjukkan bahwa 3 butir soal dengan kriteria mudah, 16 buitr soal dengan krieteria sedang, dan 4 butir soal dengan kriteria sukar.

Metode analisis data yang digunakan adalah analisis statistic deskriptif dan statistic inferensial dengan menggunakan uji-t. Statistik dekriptif yang dicari adalah mean, median, modus dan standar deviasi. Uji-t digunakan untuk menguji hipotesis penelitian. Rumus uji-t yang digunakan adalah polled varians $(n 1 \neq n 2$ dan varians homogen dengan $d b=n 1+n 2-2)$.

Uji prasyarat yang harus dilaksanakan terlebih dahulu sebelum melaksanakan uji prasyarat hipotesis adalah uji normalitas sebaran data dengan chi-kuadrat dan uji homogenitas varians dengan uji F.

\section{Hasil dan Pembahasan}

Untuk memperoleh gambaran tentang hasil belajar IPA, data dianalisis dengan analisis deskriptif agar dapat diketahui Mean (M), median (Md), Modus (Mo), dan standar deviasi. Rangkuman hasil analisis deskriptif disajikan pada table 1.

Tabel 1. Rekapitulasi Hasil Perhitungan Hasil belajar IPA

\begin{tabular}{lcc}
\hline \multicolumn{1}{c}{ Statistik Deskriptif } & Kelompok Eksperimen & Kelompok Kontrol \\
\hline Mean (M) & 14,12 & 9,75 \\
Median (Md) & 14,50 & 9,42 \\
Modus (Mo) & 15,72 & 8,74 \\
Varians & 20,58 & 19,73 \\
Standar Deviasi & 4,52 & 4,44 \\
Skor Min. & 3 & 2 \\
Skor Max. & 20 & 18 \\
Rentangan & 18 & 18 \\
\hline
\end{tabular}

Berdasarkan tabel 1, diketahui mean (M) kelompok eksperimen lebih besar daripada mean (M) kelompok kontrol. Kemudian data hasil belajar IPA dapat disajikan ke dalam bentuk kurva poligon seperti pada Gambar 1 


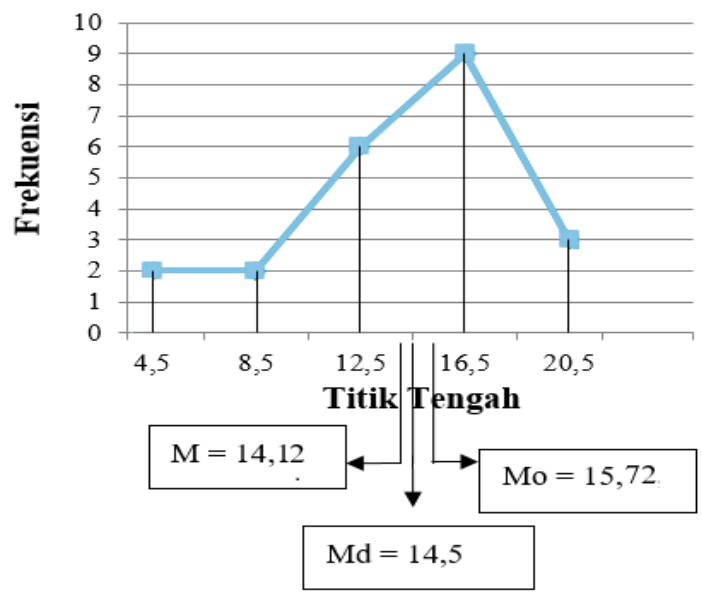

Gambar 1. Poligon Data Hasil Belajar IPA Siswa Kelompok Eksperimen

Mean (M), Median (Md), Modus (Mo) digambarkan dalam kurva poligon di atas merupakan kurva juling negatif $\mathrm{Mo}>\mathrm{Md}>\mathrm{M}(15,72>14,50>14,12)$. Hal ini menunjukkan bahwa sebagian besar skor siswa kelompok eksperimen yang dibelajarkan dengan model pembelajaran kooperatif tipe kancing gemerincing cenderung tinggi. Jika nilai rata-rata dikonversikan ke dalam penilaian skala lima berada pada kategori tinggi.

Distribusi frekuensi data hasil belajar IPA kelompok kontrol yang dibelajarkan tidak dengan model pembelajaran kancing gemerincing disajikan pada Gambar 2.

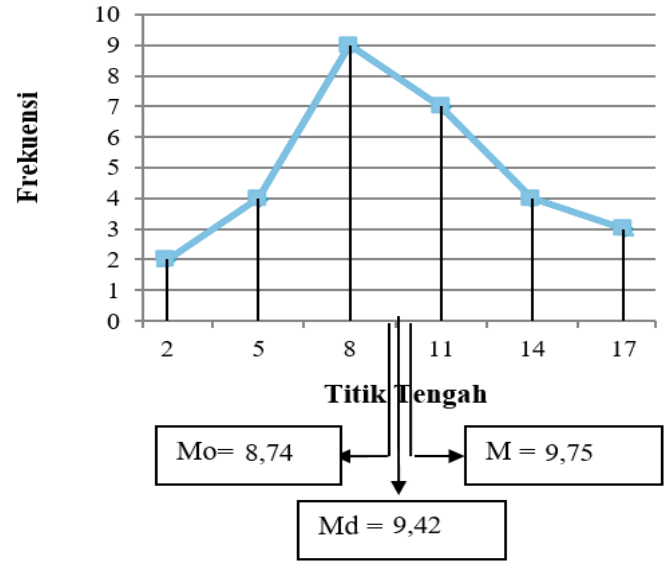

\section{Gambar 2. Poligon Data Hasil Belajar IPA Kelompok Kontrol}

Mean (M), Median (Md), Modus (Mo) digambarkan dalam grafik polygon di atas merupakan juling positif $\mathrm{Mo}<\mathrm{Md}<\mathrm{M}(8,74<9,42<9,75)$. Hal ini menunjukkan bahwa sebagian besar skor siswa kelompok kontrol cenderung rendah. Jika nilai rata-rata dikonversi ke dalam penilaian skala lima berada pada kategori sedang.

Sebelum melakukan uji hipotesis terlebih dahulu dilakukan uji prasyarat yang meliputi uji normalitas dilakukan untuk membuktikan bahwa frekuensi data penelitian benar-benar berdistribusi normal. Hasil uji normalitas sebaran data didapatkan $\chi^{2}$ hitung hasil post-test kelompok eskperimen sebesar 2,73 dan $\chi^{2}$ tabel dengan derajat kebebasan $(\mathrm{db})=2$ pada taraf signifikansi $5 \%$ adalah 5,99 . Hal ini berarti $\chi^{2}$ hitung hasil post-test kelompok eksperimen lebih kecil dari $\chi_{\text {tabel }}^{2}(2,72<5,99)$. Sehingga data hasil post-test kelompok eksperimen 
berdistribusi normal. Sedangkan $\chi^{2}$ hitung hasil post-test kelompok kontrol adalah 1,36 dan $\chi^{2}$ tabel hasil post-test kelompok kontrol dengan derajat kebebasan $(\mathrm{db})=3$ pada taraf signifikansi $5 \%$ adalah 7,81. Hal ini berarti $\chi^{2}$ hitung hasil post-test kelompok kontrol lebih kecil dari $\chi_{\text {tabel }}^{2}(1,36<7,81)$. Sehingga data hasil post-test kelompok kontrol berdistribusi normal.

Uji homogenitas varians dilakukan terhadap varians pasangan antar kelompok eksperimen dan kontrol. Uji yang digunakan adalah uji $F$ dengan kriteria data homogen jika $F_{\text {hitung }}<F_{\text {tabel }}$. Berdasarkan hasil perhitungan uji homogenitas didapatkan $F_{\text {hitung }}$ sebesar 1,04 sedangkan $F_{\text {tabel }}$ dengan $\mathrm{db}_{\text {pembilang }}=21, \mathrm{db}_{\text {penyebut }}=28$, pada taraf signifikansi $5 \%$ adalah 1,9 . Hal ini berarti $F_{\text {hitung }}$ lebih kecil dari $F_{\text {tabel }}(1,04<1,95)$ sehingga dapat dinyatakan bahwa varians data hasil post-test kelompok eksperimen dan kontrol adalah homogen.

Berdasarkan hasil analisis uji prasyarat hipotesis, diperoleh bahwa data hasil belajar IPA siswa kelompok eksperimen dan kontrol adalah normal dan homogen, sehingga pengujian hipotesis penelitian dengan uji-t dapat dilakukan. Uji hipotesis dilakukan dengan menggunakan statistic uji-t dengan rumus polled varians. Kriteria pengujian adalah $\mathrm{H}_{0}$ ditolak jika thitung $>$ tabel. Pengujian dilakukan pada taraf signifikansi $5 \%$ dengan derajat kebebasan $(\mathrm{dk})=\mathrm{n}_{1}+\mathrm{n}_{2}-2$. Hasil perhitungn uji-t dapat dilihat dalam Tabel 2.

Tabel 2. Hasil Perhitungan Uji-t

\begin{tabular}{ccccccc}
\hline Data & Kelompok & $\mathrm{N}$ & $X$ & $\mathrm{~s}^{2}$ & thit & ttab \\
\hline Hasil & Eksperimen & 22 & 14,12 & 20,58 & & \\
Belajar & Kontrol & 29 & 9,75 & 19,73 & 3,65 & 2,01 \\
IPA & & & &
\end{tabular}

Berdasarkan hasil perhitungan tersebut di atas, didapatkan thitung sebesar 3,65. Sedangkan tabel pada taraf signifikansi $5 \%$ adalah 2,01. Hasil perhitungan tersebut menunjukkan bahwa thitung lebih besar dari tabel $(3,65>2,01)$ sehingga $\mathrm{H}_{0}$ ditolak dan $\mathrm{H}_{1}$ diterima. Dengan demikian dapat diinterpretasikan bahwa terdapat perbedaan hasil belajar IPA yang signifikan antara kelompok siswa yang dibelajarkan dengan model pembelajaran kooperatif tipe kancing gemerincing dan kelompok siswa yang dibelajarkan tidak menggunakan model pembelajaran kooperatif tipe kancing gemerincing pada siswa kelas V di SD Gugus IV Kecamatan Sidemen tahun pelajaran 2017/2018.

Berdasarkan hasil perhitungan diatas menyatakan bahwa, $\mathrm{H}_{0}$ ditolak dan $\mathrm{H}_{1}$ diterima. Hasil analisis data diperoleh dari rata-rata skor hasil belajar siswa dan hasil uji-t. Rata-rata skor hasil belajar siswa yang dibelajarkan dengan model pembelajaran kooperatif tipe kancing gemerincing adalah 14,12 dan rata-rata skor hasil belajar siswa yang dibelajarkan tidak menggunakan model pembelajaran kooperatif tipe kancing gemerincing adalah 9,75. Hal ini menunjukkan bahwa rata-rata skor hasil belajar kelompok siswa yang dibelajarkan dengan model pembelajaran kooperatif tipe kancing gemerincing lebih tinggi dibandingkan skor ratarata kelompok siswa yang dibelajarkan tidak menggunakan model pembelajaran kooperatif tipe kancing gemerincing. Kemudian, berdasarkan hasil uji hipotesis menggunakan uji-t, diketahui $t_{\text {hitung }}=3,65$, dan $t_{\text {tabel }}$ pada taraf signifikansi $5 \%=2,01$. Hasil perhitungan tersebut menunjukkan bahwa $t_{\text {hitung }}$ lebih besar dari $t_{\text {tabel }}\left(t_{\text {hitung }}>t_{\text {tabel }}\right)$, sehingga hasil penelitian adalah signifikan. Dengan demikian dapat disimpulkan bahwa terdapat perbedaan yang signifikan tehadap hasil belajar IPA antara kelompok siswa yang dibelajarkan dengan model pembelajaran kooperatif tipe kancing gemerincing dan kelompok siswa yang dibelajarkan tidak menggunakan model pembelajaran kooperatif tipe kancing gemerincing.

Temuan-temuan penelitian yaitu membandingkan perbedaan yang terdapat antara kelompok siswa yang mengikuti pembelajaran dengan model pembelajaran kooperatif kancing gemerincing dan kelompok siswa yang mengikuti pembelajaran tidak menggunakan model pembelajaran kooperatif tipe kancing gemerincing disebabkan karena perbedaan perlakuan pada langkah-langkah pembelajaran dan proses penyampaian materi merupakan kombinasi antara belajar secara kooperatif dengan belajar secara individu. Siswa tetap dikelompokkan, 
tetapi siswa belajar sesuai dengan kemampuan dan kecepatan masing-masing dengan mengerti dan memahami semua materi yang diberikan serta melatih sikap teliti dan ketepatan siswa dalam menjawab soal. Masing-masing anggota kelompok saling membantu dan mengecek, sehingga kesulitan yang dialami siswa dapat dipecahkan bersama dengan anggota kelompok serta siswa dapat bimbingan guru. Kelompok ini dapat pula meningkatkan interaksi antar siswa dengan kelompoknya maupun siswa dengan kelompok lainnya. Hal ini menjadikan siswa lebih teliti dan tepat dalam menjawab setiap permasalahan yang mereka teliti, sehingga memberikan pengaruh positif terhadap hasil belajar IPA.

Pada proses pembelajaran IPA yang dilakukan dalam kelas, pada pembelajaran kooperatif tipe kancing gemerincing seluruh rangkaian kegiatan pembelajaran yang berlangsung menjadi efektif. Penerapan pembelajaran kooperatif tipe kancing gemerincing, membiasakan siswa bersikap teliti dalam segala kegiatan pembelajaran yang telah mereka lakukan, siswa saling membantu anggota kelompoknya dalam menjawab pertanyaan yang diajukan oleh guru sehingga berpengaruh positif terhadap peningkatan hasil belajar IPA. Setiap hasil pembelajaran siswa akan dinilai oleh guru, guru dapat melihat perkembangan siswa dalam memahami materi yang telah diajarkan. Siswa yang mendapatkan hasil yang kurang akan dibimbing untuk mendapatkan hasil yang lebih baik dalam setiap pembelajaran yang dilakukan.

Hal inilah yang menjadi keunggulan dari model pembelajaran kooperatif tipe kancing gemerincing dibandingkan dengan pembelajaran yang diterapkan oleh guru sehari-hari. Pembelajaran yang dilaksanakan lebih berpusat pada guru (teacher centered). Dengan kata lain, guru adalah penentu jalannya proses pembelajaran. Hal ini membuat siswa lebih banyak belajar IPA secara prosedural. Siswa berperan sebagai pendengar yang tidak aktif dan mengerjakan apa yang disuruh guru serta melakukannya sesuai dengan yang dicontohkan. Guru dalam menyampaikan materi pelajaran lebih banyak menggunakan metode ceramah sehingga menyebabkan pembelajaran menjadi bersifat teoritis dan abstrak. Selain metode ceramah, guru juga menerapkan metode tanya jawab dan latihan soal yang berlangsung terus menerus. Penerapan metode tanya jawab yang dilakukan oleh guru tidak banyak memberikan kesempatan kepada siswa untuk mengembangkan diri dan melaksanakan tanya jawab multi arah (guru-siswa, siswa-siswa, dan siswa-guru) sehingga siswa tidak mengembangkan kemampuannya dalam mengemukakkan pendapat. Siswa secara pasif hanya menerima informasi yang diberikan oleh guru dan tidak diberi kesempatan untuk mengontruksi pengetahuannya sendiri sehingga pengalaman belajar siswa menjadi terbatas, hanya sekedar mendengarkan. Pembelajaran seperti ini membuat siswa tidak terlatih untuk berinvestigasi dan hanya akan menunggu perintah guru. Pemahaman yang diperoleh tentunya bersifat sementara karena pengetahuan yang diperoleh siswa hanya berdasarkan dari informasi guru, tidak ada interaksi timbal balik. Hal ini menyebabkan rendahnya hasil belajar IPA siswa.

Hasil penelitian ini sejalan dengan hasil dari beberapa penelitian tentang pengaruh model pembelajaran kooperatif tipe kancing gemerincing. Gst. A. Eka Yunda Dewi (2012) melakukan penelitian eksperimen mengenai pengaruh penerapan model pembelajaran kooperatif tipe kancing gemerincing terhadap hasil belajar IPS siswa kelas V SD gugus IVI kecamatan Tejakula. Hasil penelitiannya menujukkan bahwa hasil belajar IPS siswa kelas V SD $\mathrm{N}$ gugus IVI kecamatan Tejakula yang mengikuti proses pembelajaran dengan model pembelajaran kooperatif tipe kancing gemerincing lebih baik dari hasil belajar IPS siswa yang mengikuti pembelajaran konvensional. I Md Saputra (2013) melakukan penelitian tentang implementasi model pembelajaran kooperatif tipe kancing kemerincing untuk meningkatkan aktivitas dan hasil belajar IPA siswa kelas V SDN I Duda Utara. Dalam penelitiannya diperoleh bahwa model pembelajaran kancing gemerincing dalam pembelajaran IPA mampu meningkatkan aktivitas dan hasil belajar siswa. I Putu Sumarta (2012) melakukan penelitian tentang implementasi model pembelajaran kooperatif tipe kancing gemerincing untuk meningkatkan aktivitas dan hasil belajar matematika siswa kelas IVB semester ganjil SD Mutiara Singaraja tahun pelajaran 2012/2013. Dalam penelitiannya diperoleh bahwa pengaruh 
model pembelajaran kooperatif tipe kancing gemerincing dalam pembelajaran matematika mampu meningkatkan aktivitas dan hasil belajar siswa.

\section{Simpulan dan Saran}

Berdasarkan hasil penelitian dan pembahasan, dapat disimpulkan bahwa terdapat perbedaan yang signifikan pada hasil belajar IPA antara kelompok siswa yang dibelajarkan dengan model pembelajaran kooperatif tipe kancing gemerincing dan kelompok siswa yang dibelajarkan tidak menggunakan model pembelajaran kooperatif tipe kancing gemerincing pada siswa kelas V semester I di SD Gugus IV Kecamatan Sidemen tahun pelajaran 2017/2018. Hal tersebut diperoleh dari hasil perhitungan uji-t, thitung sebesar 3,65, sedangkan, ttabel (dengan $\mathrm{db}=49$ dan taraf signifikansi 5\%) adalah 2,01. Hal ini berarti, thitung lebih besar dari ttabel (thitung > ttabel), sehingga $\mathrm{HO}$ ditolak dan $\mathrm{H} \neg 1$ diterima. Dari rata-rata ( ) hasil belajar IPA, diketahui ( ) kelompok eksperimen sebesar 14,12 dan ( ) kelompok kontrol sebesar 9,75. Hal ini berarti ( ) eksperimen > ( ) kontrol. Dengan demikian, model pembelajaran kooperatif tipe kancing gemerincing berpengaruh terhadap hasil belajar IPA siswa.

Saran yang diharapkan dari penelitian yang telah dilakukan adalah sebagai berikut. Secara teoretis, penelitian ini dapat memberikan kontribusi mengenai model pembelajaran yang inovatif untuk menunjang proses pembelajaran. Selain itu, terdapat beberapa saran yang diberikan kepada pihak yang terkait yaitu sebagai berikut. 1) Disarankan kepada siswa, Dengan digunakannya model pembelajaran kooperatif tipe kancing gemerincing pada mata pelajaran IPA, diharapkan para siswa dapat melaksanakan pembelajaran dengan baik dan menyenangkan. 2) Disarankan agar guru dapat menerapkan model pembelajaran kancing dalam pembelajaran IPA sehubungan dengan upaya meningkatkan hasil belajar sehingga guru bisa menjadi fasilitator yang menyenangkan dalam proses pembelajaran di kelas. Jadi, akan tercipta proses pembelajaran yang terpusat pada siswa, efektif, dan efisien. 3) Disarankan kepada kepala sekolah agar selalu berusaha meningkatkan kualitas pembelajaran di sekolah, salah satunya dengan cara mengambil kebijakan untuk menentukan strategi pembelajaran efektif dan efisien serta mensosialisasikan penerapan suatu model pembelajaran yang inovatif, sehingga hasil belajar siswa meningkat. 4) Disarankan kepada peneliti lain yang berminat mengadakan penelitian lebih lanjut mengenai model pembelajaran kooperatif tipe kancing gemerincing dapat menjadikan hasil penelitian ini sebagai salah satu referensi untuk meneliti dalam lingkup yang lebih luas, sehingga diperoleh sumbangan ilmu yang lebih baik dan sesuai dengan perkembangan zaman.

\section{Daftar Pustaka}

Lie, Anita. 2004. Cooperatif Learning. Cetakan Keempat. Jakarta: PT Grasindo.

Miftahul, Huda. 2011. Cooperative Learning.Yogyakarta: Pustaka Pelajar.

Saputra. 2013. Implementasi Model Pembelajaran Kooperatif Tipe kancing Gemerincing Untuk Meningkatkan Aktivitas dan Hasil Belajar IPA Siswa Kelas V SDN I Duda Utara. Tersedia pada:

http://ejournal.undiksha.ac.id. Diakses pada tanggal 05 Januari 2017.

Sugianto. 2010. Model-model Pembelajaran Inovatif. Surakarta: Yuma Pustaka.

Sumarta, Putu.2012. Implementasi Model Pembelajaran Kooperatif Tipe Kancing Gemerincing Untuk Meningkatkan Aktivitas dan Hasil Belajar Matematika Siswa Kelas IVB Semester Ganjil SD Mutiara Singaraja Tahun Pelajaran 2012/2013. Tersedia pada: http://ejournal.undiksha.ac.id Diakses pada tanggal 03 Mei 2017. 
Yunda, Eka. 2012. Pengaruh Penerapan Model Pembelajaran Kooperatif tipe Kancing Gemerincing Terhadap Hasil Belajar IPS Siswa Kelas V SD Gugus IVI Kecamatan Tejakula. Tersedia pada:http://ejournal.undiksha.ac.id Diakses pada tanggal 05 Januari 2017. 